\title{
Chemical composition of weathering products in neutral and acidic mine tailings from stibnite exploitation in Slovakia
}

\author{
Tomáš KLIMKO ${ }^{*}$, Bronislava LALINSKÁ , Juraj MAJZLAN², Martin CHOVAN, Gabriela KUČEROVÁ1, \\ Christin PAUL ${ }^{2}$
}

\author{
${ }^{1}$ Department of Mineralogy and Petrology, Comenius University, Mlynská dolina G, 84215 Bratislava, Slovakia; klimkotomas@gmail. \\ com \\ 2 Institute of Geosciences, Burgweg 11, Friedrich-Schiller University, 07749 Jena, Germany \\ ${ }^{*}$ Corresponding author
}

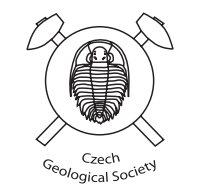

Here we describe the chemical composition of the weathering products at two abandoned stibnite deposits, Dúbrava and Poproč in Slovakia. The tailings at Dúbrava are circumneutral ( $\mathrm{pH} 7-8)$, richer in Sb than As and rich in carbonates. The tailings at Poproč are acidic ( $\mathrm{pH} 3-5)$, the Sb/As ratio is usually close to 1, carbonates are missing, and the tailings have elevated $\mathrm{Pb}$ contents. The most common sulphide at both sites was pyrite $\left(\mathrm{FeS}_{2}\right)$, less frequently stibnite $\left(\mathrm{Sb}_{2} \mathrm{~S}_{3}\right)$ and arsenopyrite $(\mathrm{FeAsS})$; minor berthierite $\left(\mathrm{FeSb}_{2} \mathrm{~S}_{4}\right)$ was found only at Poproč. At both sites, sandy layers of the tailings contain the weathering products; the clayey portions are sterile. The most frequent secondary phases in the Dúbrava impoundments are oxidation rims on pyrite and arsenopyrite, with relics of the primary sulphides commonly preserved. At Poproč, the primary sulphides were completely oxidized and decomposed. A common feature of the oxidation rims on all primary sulphides is their enrichment with respect to elements rather rare in the primary phase, an effect which is most apparent in the outermost portions of the rims. Rims around arsenopyrite may be enriched in Sb, around pyrite in As and $\mathrm{Sb}$, and around stibnite in $\mathrm{Pb}$. Antimony is usually incorporated into $\mathrm{Sb}-\mathrm{Fe}, \mathrm{Fe}-\mathrm{Sb}$, $\mathrm{Sb}$, or $\mathrm{Sb}-\mathrm{Ca}$ oxides, with the $\mathrm{Sb} /(\mathrm{Sb}$ $+\mathrm{Fe})$ ratio varying from 0 to 1 . Arsenic behaves differently in comparison with $\mathrm{Sb}$ in that the highest $\mathrm{As} /(\mathrm{As}+\mathrm{Fe}) \mathrm{ratio}$ on a wt. \% basis is 0.41 , as observed in weathering rims on arsenopyrite, the only primary sulphide with a substantial As content. Our results show that the nature of the weathering products is controlled by the primary mineralogy and the ability of the aqueous solutions to transport $\mathrm{As}, \mathrm{Sb}, \mathrm{Ca}, \mathrm{Fe}$, and $\mathrm{Pb}$. There is no indication that the final products would be chemically or mineralogically different if weathering reached the terminal stages at the two studied sites.

Keywords: weathering, tailings, antimony, arsenic, Slovakia

Received: 28 February 2011; accepted: 3 August 2011; handling editor: S. Mills

The online version of this article (doi: 10.3190/jgeosci.104) contains supplementary electronic material.

\section{Introduction}

The oxidation of sulphide minerals in mine tailings usually leads to the release of many elements into aqueous media. The concentration of these elements often exceeds that acceptable for living organisms or permissible by law. The quantity and quality of the sulphide weathering products depends on the availability of oxidizing agents (dissolved $\mathrm{O}_{2}, \mathrm{Fe}^{3+}$ ), the nature and composition of the sulphides and their reactive surface area, physical parameters of the tailings (porosity, particle size distribution), climate, water saturation level of the pores, water in- and outflow to and from the impoundment, and chemical and biochemical reactions in its interior (Nicholson 1994; Ritchie 1994; Seal and Hammarstrom 2003). Sulphide oxidation leads to the generation of sulphuric acid which can be neutralized by carbonate minerals such as calcite or dolomite. Aluminosilicate minerals such as plagioclase can also consume acid, even though they are not as reactive as carbonates (Plumlee 1999; Jambor et al. 2002).
The oxidation of pyrite $\left(\mathrm{FeS}_{2}\right)$, the most common cause of acid mine drainage, has been described by many authors (Lowson 1982; Davis and Ritchie 1986; Jambor 1994, 2003). Similarly, oxidation processes involving arsenopyrite (FeAsS) are relatively well known (Buckley and Walker 1988; Richardson and Vaughan 1989; Nesbitt et al. 1995; Nesbitt and Muir 1998; Corkhill and Vaughan 2009). The weathering products in tailings rich in pyrite or pyrrhotite $\left(\mathrm{Fe}_{1-x} \mathrm{~S}\right)$ have been described in detail (Jambor 1994; Blowes et al. 2003). In contrast, little is known about oxidation of antimony sulphides, especially stibnite $\left(\mathrm{Sb}_{2} \mathrm{~S}_{3}\right)$ and the distribution of antimony in the environment (Živković et al. 2002; Ashley et al. 2003; Flynn et al. 2003; Scheinost et al. 2006; Ackermann et al. 2009).

A detailed study of the chemistry of the weathering products is an important step toward the comprehension of the complex processes operating in the mine tailings environment. Identification of the carriers of the pollutants is a prerequisite for the assessment of the contamination risk and a remediation or immobilization strategy. 
In this study, we compare sulphide oxidation processes and the resulting chemical compositions of the weathering products within several $\mathrm{Fe}-$, $\mathrm{Sb}$ - and As-rich tailing ponds (impoundments) from two abandoned stibnite deposits in Slovakia. Differences between the two localities selected are the petrology of the host rocks, mineralogy of the primary hydrothermal ores, concentrations of the toxic elements, $\mathrm{pH}$ values of the tailings, technical characteristics of the tailing impoundments, age of the deposited sediments, and climatic conditions.

\section{Description of the study sites}

\subsection{Dúbrava deposit}

The first report of mining activities at the Dúbrava deposit dates back to the beginning of the $18^{\text {th }}$ century. The period of the most intense mining began in 1944 when the oldest impoundment was established. Between 1944 and the end of the mining operation in 1991, the deposit produced 1300000 metric tons of ore and 22000 metric tons of antimony, placing it among the biggest world $\mathrm{Sb}$ producers (Arvensis et al. 1994).

Hydrothermal veins and diagonal veinlets contain stibnite and pyrite as the major ore minerals; minor phases include arsenopyrite, zinkenite $\left(\mathrm{Pb}_{9} \mathrm{Sb}_{22} \mathrm{~S}_{42}\right)$, sphalerite $(\mathrm{ZnS})$, and tetrahedrite $\left(\mathrm{Cu}_{12}(\mathrm{Sb}, \mathrm{As})_{4} \mathrm{~S}_{13}\right)$. The most frequent gangue minerals are quartz and dolomite (Chovan et al. 1994). Abundant illite, chlorite, and carbonates formed in the host rocks during hydrothermal alteration (Orvošová et al. 1998). Country rocks of the Dúbrava deposit are predominantly biotite granodiorites and tonalites with smaller elongated bodies of migmatites and gneisses which represent relics of the crystalline basement.

The ores were milled in two steps (dry and wet) in ball mils to a grain size under $0.071 \mathrm{~mm}$ and stibnite was extracted by flotation with a recovery factor for $\mathrm{Sb}$ of $85 \%$ (Arvensis et al. 1994). The waste was deposited in four impoundments situated in the Križianka creek valley (Fig. 1). The tailing ponds at Dúbrava are conventional raised embankment tailings storage facilities but with no impermeable (e.g., clay) layer at their bases. The tailings lie directly on alluvial sediments. After mining operations ceased, the impoundments were covered by a mixture of soil and rocks to lessen the contact of the tailings with atmospheric oxygen and water. The old impoundment was covered by $2.5-3 \mathrm{~m}$ of industrial waste, the impoundment no. 2 by $20 \mathrm{~cm}$ of soil, and the impoundments 1 and 3 by up to $1 \mathrm{~m}$ of industrial waste.

Climate in this region is moderately warm and humid, with average temperature in January of $5-8^{\circ} \mathrm{C}$, average temperature in July of $14-16{ }^{\circ} \mathrm{C}$ and average annual precipitation $900 \mathrm{~mm}$.

\subsection{Poproč deposit}

At Poproč, exploitation of $\mathrm{Sb}$ ores started in the $17^{\text {th }}$ century and the mines were closed in 1965. The most intense mining took place between 1931 and 1965 when more than 10000 metric tons of antimony and c. $80 \mathrm{~kg}$ of gold were recovered (Kaličiaková et al. 1996).

The main minerals of the hydrothermal veins are quartz and stibnite, with less common pyrite, arsenopyrite, berthierite $\left(\mathrm{FeSb}_{2} \mathrm{~S}_{4}\right)$, tetrahedrite, sphalerite, and the $\mathrm{Pb}-\mathrm{Sb}$ sulphosalts zinkenite and fülöppite $\left(\mathrm{Pb}_{3} \mathrm{Sb}_{8} \mathrm{~S}_{15}\right)$ (Klimko et al. 2009). The Poproč deposit is hosted by Early Paleozoic low-grade metapelites and acid metapyroclastics which were later intruded by Permian granites (Grecula et al. 1995).

Tailings from the Poproč deposit were more or less scattered in local geographic depressions or other suitable locations, sometimes even without dams to protect their flanks and a layer of clays or at least industrial waste to diminish the rate of oxidation. At several points, the tailings are in a direct contact with surface waters. In this study, we divided these scattered tailings storage pools into three impoundments situated in the valley under the mine (Fig. 1). The biggest one (tailing impoundment no. 3) carries about $18000 \mathrm{~m}^{3}$ of sediments (Kaličiaková et al. 1996), tailing impoundments 1 and 2 are smaller.

Climate in this region is moderately warm and humid, with average annual temperatures of $5-8{ }^{\circ} \mathrm{C}$ and an average annual precipitation of $900 \mathrm{~mm}$.

\section{Materials and methods}

\subsection{Sample collection and preparation}

Samples of the tailing material at Dúbrava were collected from two boreholes, one situated in the old impoundment (borehole DU-1, entire length $13.5 \mathrm{~m}$ ), and the second one in the impoundment no. 2 (borehole DU-3, entire length $20 \mathrm{~m}$ ) (Fig. 1). In both cases, the boreholes penetrated the tailings from the top layers into the eluvial sediments. Samples from the impoundment no. 3 were collected from a well (DUT-7) dug to a depth of approximately $2 \mathrm{~m}$.

At the Poproč deposit, where tailing impoundments were not built at any prearranged sites, samples were collected from profiles on the exposed slopes of the impoundment no. 3 (POT-3) and from dug wells in the impoundments no. 1 (POT-1) and no. 3 (POT-2) (Fig. 1).

The samples were composites of $20-100 \mathrm{~cm}$ of the profile in the boreholes or the dug wells. These were homogenized and two thirds of each sample separated into light and heavy fraction by panning in water or in ethanol. Selected heavy-grain concentrates were prepared 
for further study in a form of standard thin and polished sections, to be inspected in transmitted and reflected polarized light, respectively. The remainder of each sample was used for geochemical study and $\mathrm{pH}$ measurements.

Chemical compositions of the samples were determined by X-ray fluorescence (XRF) analyses with a Philips PW 2400 instrument (Friedrich-Schiller University, Jena, Germany). The samples were finely ground, mixed with wax, and pressed into pellets. For all elements except $\mathrm{As}$ and $\mathrm{Sb}$, the standard materials used for rock analysis were applied. For the two metalloids, we used home-made secondary standards made of finely-ground granite with admixed known amounts of $\mathrm{As}$ and $\mathrm{Sb}$ to derive calibration curves.

The $\mathrm{pH}$ values were measured in a suspension of tailings sediments with water $(10: 1)$ which was allowed to stand for 24 hours prior to measurement (Conklin 2005).
The electrode was calibrated with standard $\mathrm{pH}$ solutions (4.01 and 7.00).

The carbonate content in selected samples was measured from the volume of $\mathrm{CO}_{2}$ released by $15 \%$ hydrochloric acid. The finely ground samples were weighed out and brought into the contact with acid in a tightly sealed glass flask. The $\mathrm{CO}_{2}$ volume was read in a sealed and calibrated glass cylinder. The samples were allowed to outgas for 20-30 minutes, until the reaction stopped and the volume of gas did not increase anymore. No attempt was made to distinguish calcite, dolomite, and ankerite by this method. All data were recalculated on the basis of equivalent weight per cent of calcite, that is, the amount of calcite that would be responsible for an identical volume of $\mathrm{CO}_{2}$ released during an experiment. A sensitivity analysis carried out on samples with known carbonate (calcite) concentration of 5-10\% has
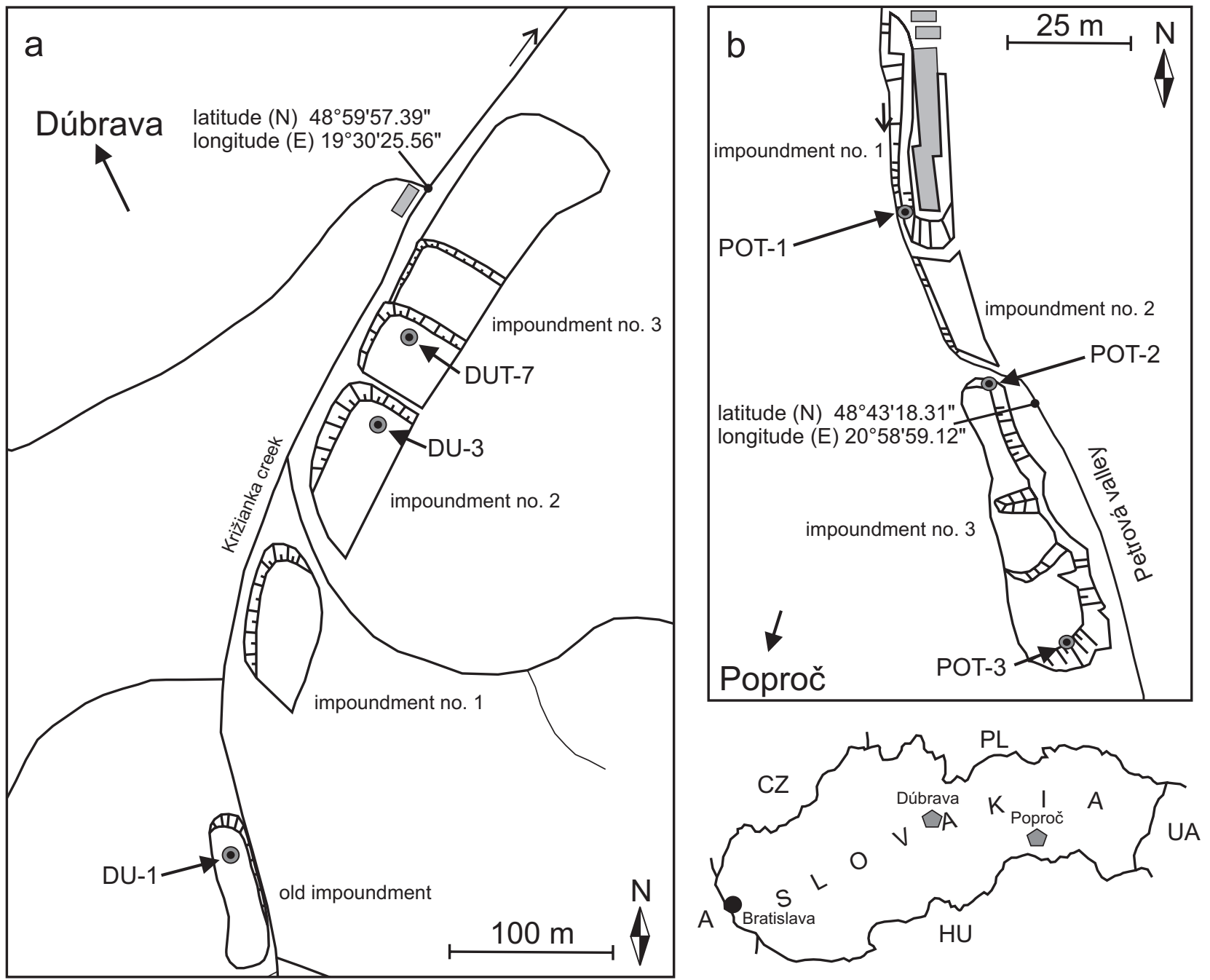

Fig. 1 Schematic maps of the study sites. The bottom right panel shows the location of both deposits in Slovakia. Each map depicts the location of tailings, the sampling sites discussed in the text and contains one point with precise geographic coordinates. 
shown that the accuracy of the method is $0.3-0.5 \%$. Repeated measurements on the samples of the impoundment sediments have shown that the standard deviation of the measurements is $0.3-1.0 \%$, increasing with decreasing carbonate content in the samples.

Neutralization potentials of the tailing materials were determined using EPA (Environmental Protection Agency (U.S)) methodology (after Sobek et al. 1978). This method is based on a treatment of the sample with a known amount of standardized $\mathrm{HCl}$. The calcium carbonate equivalent is calculated by titration of the $\mathrm{HCl}$ not consumed with standardized $\mathrm{NaOH}$ solution. The ability of the material to produce $\mathrm{H}_{2} \mathrm{SO}_{4}$ was tested by a static net acid generation test (Miller et al. 1997). In this method, the sulphides present in the sample are forced to oxidize by hot $\mathrm{H}_{2} \mathrm{O}_{2}$. The amount of generated acid is then calculated by titration with a standardized $\mathrm{NaOH}$ solution.

Quantitative mineral compositions of heavy fractions were determined by counting a statistically significant number of grains in each sample under a reflected polarized light microscope and in a scanning electron microscope. The ore minerals and their weathering products were subsequently analyzed by a Cameca SX-100 electron microprobe (State Geological Institute of Dionýz Štúr, Bratislava) in wavelength-dispersive mode (WDS) under conditions of $20 \mathrm{kV}, 20 \mathrm{nA}$, and beam size of 1-5 $\mu \mathrm{m}$. The following lines, standards, and crystals were used for the analyzed elements: $\mathrm{Mg}\left(\mathrm{K}_{\alpha}\right.$, forsterite, TAP); $\mathrm{Al}\left(\mathrm{K}_{\alpha}, \mathrm{Al}_{2} \mathrm{O}_{3}, \mathrm{TAP}\right) ; \mathrm{Si}\left(\mathrm{K}_{\alpha}, \mathrm{SiO}_{2}, \mathrm{TAP}\right) ; \mathrm{S}, \mathrm{Fe}, \mathrm{Cu}\left(\mathrm{K}_{\alpha}\right.$, $\left.\mathrm{CuFeS}_{2}, \mathrm{PET}\right) ; \mathrm{P}\left(\mathrm{K}_{\alpha}, \mathrm{GaP}, \mathrm{PET}\right)$; $\mathrm{Ca}\left(\mathrm{K}_{\alpha}\right.$, wollastonite, PET ); Mn ( $\mathrm{K}_{\alpha}$, metallic Mn, LIF); Co $\left(\mathrm{K}_{\alpha}\right.$, metallic Co, LIF); Ni ( $\mathrm{K}_{\alpha}$, metallic Ni, LIF); Zn ( $\left.\mathrm{K}_{\alpha}, \mathrm{ZnS}, \mathrm{LIF}\right), \mathrm{Pb}$ $\left(\mathrm{M}_{\alpha}, \mathrm{PbS}, \mathrm{PET}\right) ; \mathrm{Sb}\left(\mathrm{L}_{\beta}, \mathrm{Sb}_{2} \mathrm{~S}_{3}, \mathrm{PET}\right)$, As $\left(\mathrm{L}_{\beta}, \mathrm{Fe} A s S\right.$, TAP). The counting time on each peak was $20 \mathrm{~s}$, on background $10 \mathrm{~s}$ ( $20 \mathrm{~s}$ for $\mathrm{Sb}$ ). All electron microprobe analyses are available as an electronic supplement to this article.

\section{Results}

\subsection{Primary, secondary, and teriary minerals}

Primary sulphides, i.e. those which formed by the action of hydrothermal fluids as a part of the ore mineralization, can be subsequently replaced by various weathering products. We distinguish here between weathering products which were produced only naturally ('secondary minerals') and weathering products which form owing to human activities in the dumps, waste piles, and impoundments ('tertiary minerals'). Recently formed minerals appear in the tailings as oxidation rims and films on the primary sulphides or precipitates in voids between tailings particles. We suspect that most of these recently formed

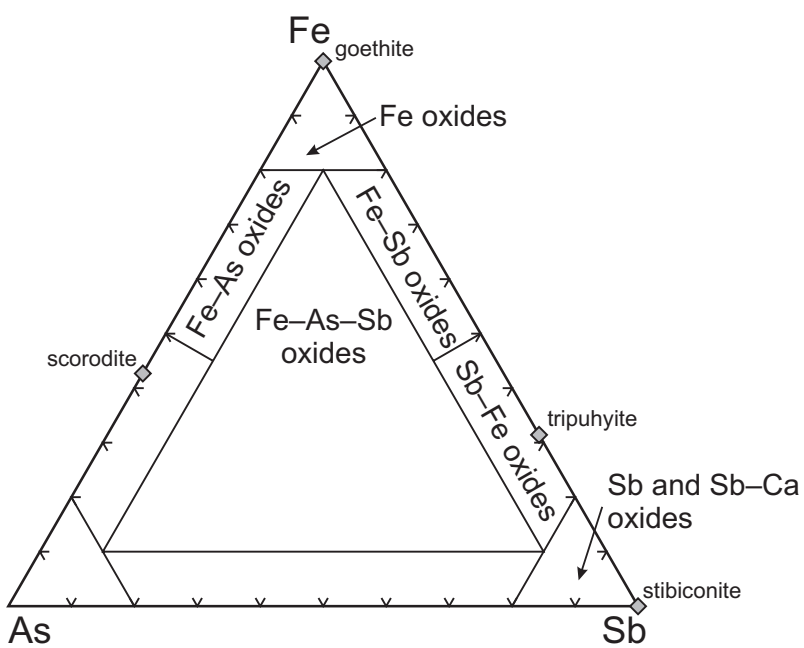

Fig. 2 A triangular diagram showing the division of the weathering products based on their chemical compositions as used in this work.

minerals are tertiary but the secondary origin of at least some of them is difficult to prove or disprove. Hence, if such distinction cannot be made, we will refer to all newly formed minerals in the studied impoundments as secondary. We should note, however, that the secondary and tertiary minerals at a single locality are not necessarily the same, even though they form from the same primary minerals. The pore waters in the impoundments are richer in many elements than the natural waters and the processes of dissolution, weathering, and precipitation run a different course.

The secondary and tertiary minerals will be collectively called here oxides, a term which includes oxides, hydroxides, and oxyhydroxides. For the discussion of the chemical composition of the weathering products, we divide them arbitrarily into several groups (see Fig. 2). The distinction is based on the projection of the chemical composition of a given material in a triangular $\mathrm{Fe}-\mathrm{Sb}-\mathrm{As}$ plot. Among the $\mathrm{Sb}$-rich weathering products, we further distinguish between $\mathrm{Sb}$ oxides and $\mathrm{Sb}-\mathrm{Ca}$ oxides. The latter are those which contain at least 5 wt. \% Ca.

\subsection{Dúbrava deposit}

\subsubsection{Geochemical characteristics of the tailings materials}

Tailings materials at Dúbrava consist of alternating sandy and clayey sediment layers of $\mathrm{mm}$ to 5 meters thickness. Alternation of the layers is easily observable, especially in the top parts of the tailings where sand prevails. Clays become more abundant with depth and in some sections of the impoundments clay-rich layers may be up to $5 \mathrm{~m}$ 

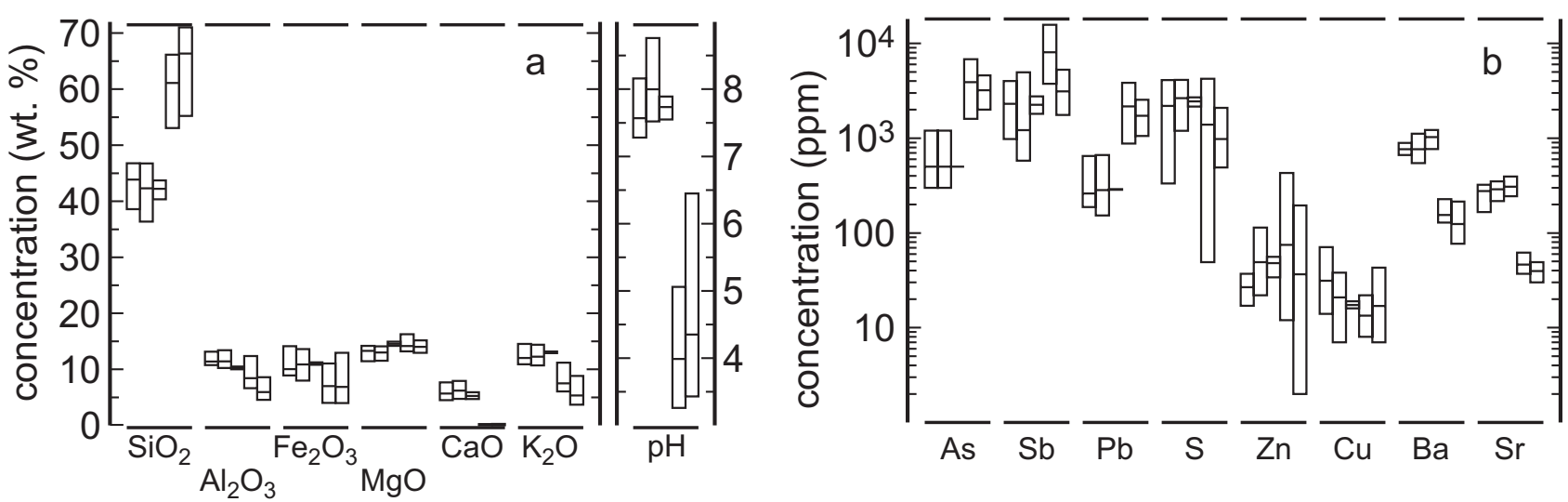

Fig. 3 Chemical composition of the tailings as determined by XRF and their $\mathrm{pH}$ : $\mathbf{a}-\mathrm{Major}$ oxides and $\mathrm{pH}$; $\mathbf{b}-\mathrm{Minor}$ and trace elements. Note that the vertical scale in panel (b) is logarithmic. The boxes represent the minima and maxima of the variables plotted, and the bar inside each box is the mean. For each variable, the five boxes plotted represent the five sampling sites in the order DU-1, DU-3, DUT-7, POT-1, POT-2.

thick (borehole DU-3, depth $850-1350 \mathrm{~cm}$ ). These clayey sediments do not contain sulphides or products of their oxidation. The concentrations of the major oxides (Fig. 3a) disagree with values expected for granodiorite or tonalite; the differences, especially lower $\mathrm{SiO}_{2}$, higher $\mathrm{Al}_{2} \mathrm{O}_{3}, \mathrm{~K}_{2} \mathrm{O}$, and $\mathrm{CaO}$ contents, are related to the pervasive illitization and carbonatization of the granitoid rocks (Orvošová et al. 1998).

Tailings at Dúbrava contain up to $5000 \mathrm{ppm} \mathrm{Sb}$ and the concentration of $\mathrm{Sb}$ usually exceeds that of As (Figs $3 b, 4)$. The $\mathrm{Pb}, \mathrm{Zn}$, and $\mathrm{Cu}$ contents are relatively low, corresponding to the minor proportion of zinkenite, sphalerite, and tetrahedrite in the ores. The presence of barite in the veins is traceable by elevated $\mathrm{Ba}$ and Sr contents.

The average $\mathrm{pH}$ value of tailings materials is 7.57 in the case of the old impoundment (borehole DU-1), 8.00 for impoundment number 2 (borehole DU-3) and 7.73 at the youngest one (DUT-7). The $\mathrm{pH}$ values in the tailings are buffered by abundant carbonates. The carbonate content measured directly (as volume of gas released in reaction with $\mathrm{HCl}$ ) varied usually between 3 and 4 wt. \% calcite equiv., with maxima of 2.0 and $5.6 \mathrm{wt}$ \%. The calculated neutralization potential of the tailings corresponds to $70-120 \mathrm{t} \mathrm{CaCO}_{3}$ per $1000 \mathrm{t}$ of tailings. The tailings at Dúbrava are not expected to produce acidity $\left(\mathrm{H}_{2} \mathrm{SO}_{4}\right)$, both according to simple calculations from the measured sulphur and carbonate contents, and the static net acid generation tests.

\subsubsection{Oxidation products of pyrite and arsenopyrite}

The most frequent sulphide in the tailings is pyrite and its crystals are often intensively corroded and replaced by secondary Fe oxides (Fig. 5). They form oxidation rims on the pyrite crystals or replace pyrite along cracks and contain 0.01 to 4.50 wt. \% As and up to 7.75 wt. \% Sb (Tab. 1). Both of the metalloids are bound predominantly in the outer parts of the rims (Fig. 6, Tab. 2). At least part of the As in these rims may have originated from the primary pyrite. Although pyrite is nominally $\mathrm{FeS}_{2}$, hydrothermal pyrite from Dúbrava is often zoned and the As concentrations in the outer parts of the crystals reach 5.17 wt. \%; the $\mathrm{Sb}$ contents in the pyrite are below the detection limit ( $\sim 0.05$ wt. \%) of the electron microprobe (Chovan 1990).

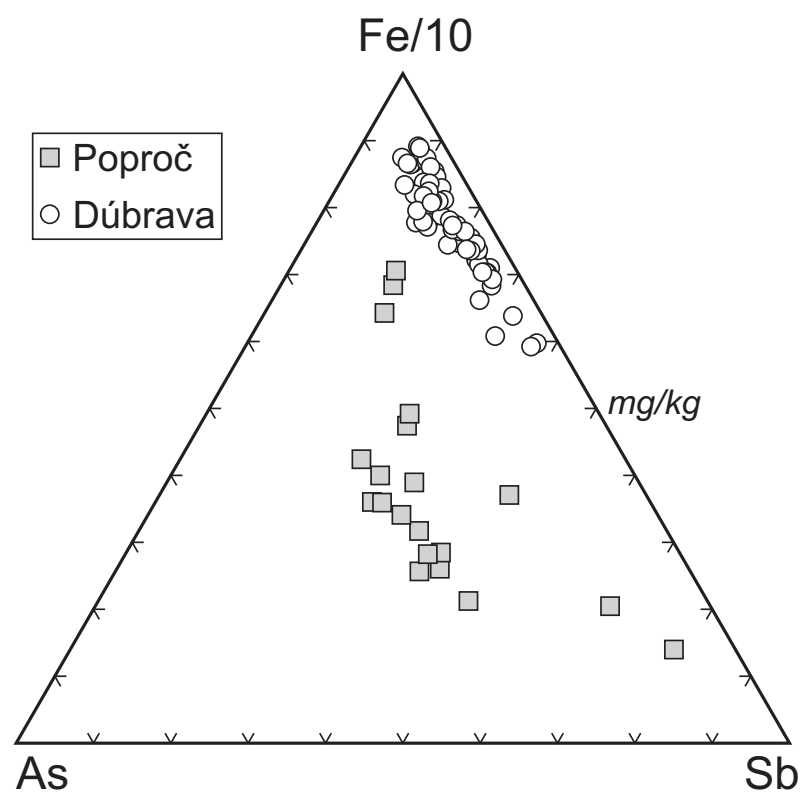

Fig. 4 A triangular plot of the chemical compositions of the tailings from Dúbrava (circles) and Poproč (squares). All data plotted are based on XRF analyses. 


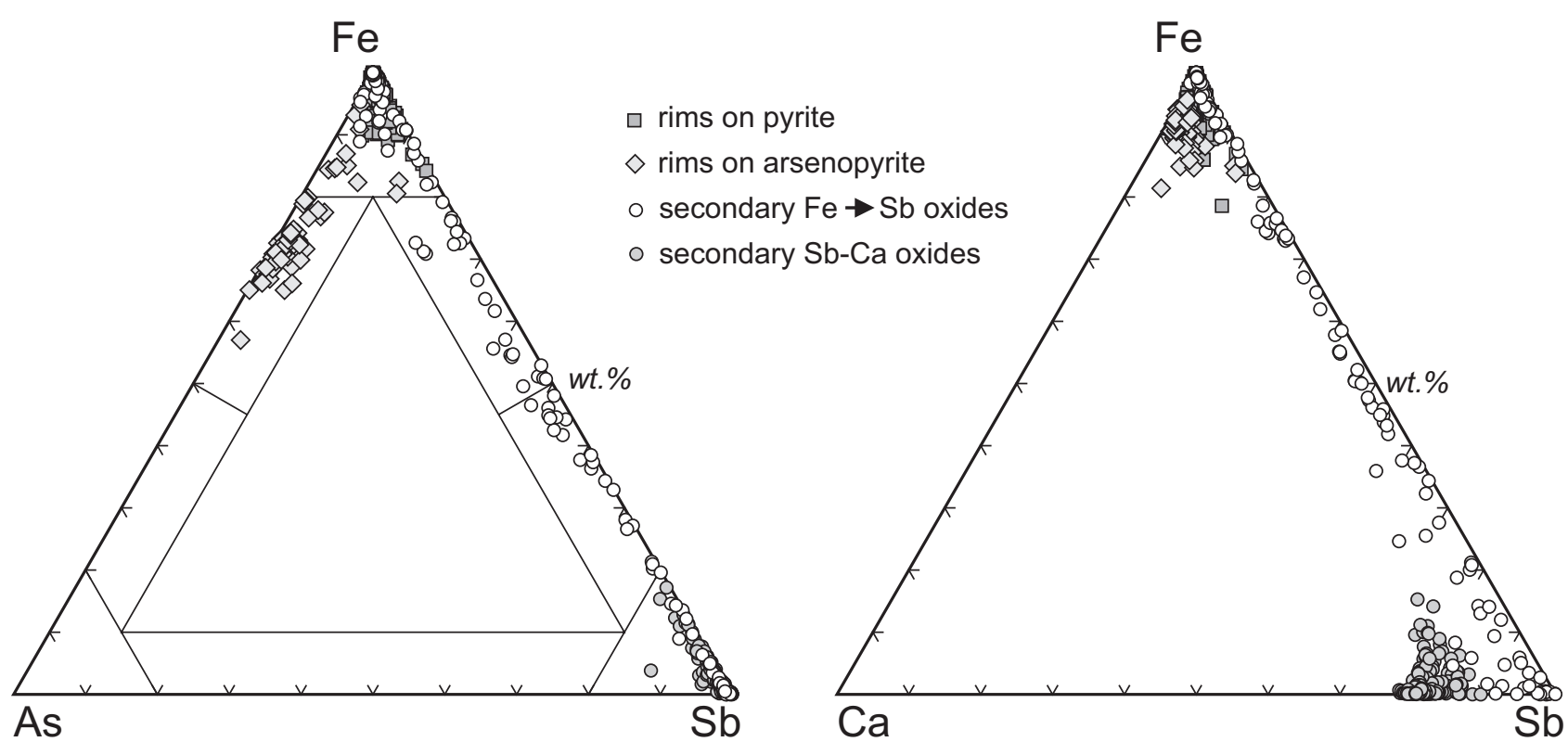

Fig. 5 Triangular plots of the chemical compositions of the rims on pyrite (squares), arsenopyrite (diamonds), and grains with no relics of primary sulphides (circles) from the tailings at Dúbrava. All data plotted are based on spot electron microprobe analyses. For the fields plotted in the left panel, see Fig. 2.

In few cases, the $\mathrm{Fe}$ oxides replaced the pyrite crystals completely, forming pseudomorphs with the original crystal shape, having $0-9.78$ wt. \% Sb and $0-2.33$ wt. \% As. Quantitative proportions of the Fe oxides are the same at all the impoundments studied. Outside of the oxidation zones, subhedral pyrite crystals show little or no visible corrosion.

In the oxidation zones of the tailings, arsenopyrite crystals are coated by oxidation rims which consist of
Fe-As or Fe oxides (Figs 5, 7a, Tab. 1). The As content in these rims (2.69-19.87 wt. \%) is lower than in primary arsenopyrite, suggesting that, during oxidation and weathering, As was partially lost to the pore solutions. The $\mathrm{Sb}$ content is also relatively high, ranging from 0.12 to $7.01 \mathrm{wt}$ \%. The $\mathrm{Sb}$ concentration in primary arsenopyrite does not exceed 1.89 wt. \% (Sahan and Chovan 1991). Outside the oxidation zones, arsenopyrite crystals are not affected by weathering and oxidation.

Tab. 1 Electron microprobe analyses of the weathering products from Dúbrava (wt. \%)

\begin{tabular}{|c|c|c|c|c|c|c|c|}
\hline & $\begin{array}{c}\text { rims on } \\
\text { arsenopyrite }\end{array}$ & $\begin{array}{l}\text { rims on } \\
\text { pyrite }\end{array}$ & Fe oxides & $\mathrm{Fe}-\mathrm{Sb}$ oxides & $\mathrm{Sb}-\mathrm{Fe}$ oxides & Sb oxides & $\mathrm{Sb}-\mathrm{Ca}$ oxides \\
\hline element $/ n$ & 73 & 159 & 32 & 16 & 10 & 23 & 140 \\
\hline $\mathrm{Mg}$ & $0.36(0.07)$ & $0.25(0.14)$ & $1.57(3.34)$ & $0.16(0.05)$ & $0.10(0.05)$ & $0.06(0.03)$ & $0.13(0.04)$ \\
\hline $\mathrm{Al}$ & $0.23(0.81)$ & $0.34(1.86)$ & $0.36(0.64)$ & $0.20(0.25)$ & $0.15(0.18)$ & $0.04(0.05)$ & $0.10(0.18)$ \\
\hline $\mathrm{Si}$ & $0.66(0.54)$ & $1.74(2.31)$ & $1.25(1.16)$ & $0.93(0.70)$ & $0.50(0.29)$ & $0.44(0.25)$ & $1.33(0.50)$ \\
\hline S & $0.43(0.70)$ & $0.71(2.30)$ & $0.18(0.75)$ & $0.90(1.95)$ & $0.14(0.23)$ & $0.08(0.11)$ & $0.05(0.12)$ \\
\hline $\mathrm{P}$ & $0.01(0.02)$ & $0.07(0.15)$ & $0.12(0.21)$ & $0.12(0.08)$ & $0.15(0.14)$ & $0.02(0.04)$ & $0.02(0.04)$ \\
\hline $\mathrm{Ca}$ & $2.91(0.64)$ & $1.22(0.96)$ & $0.41(0.24)$ & $1.19(0.40)$ & $1.01(0.75)$ & $1.84(1.55)$ & $8.63(1.27)$ \\
\hline $\mathrm{Mn}$ & $0.02(0.05)$ & $0.03(0.10)$ & $0.37(0.48)$ & $0.12(0.11)$ & $0.08(0.12)$ & $0.03(0.04)$ & $0.04(0.05)$ \\
\hline $\mathrm{Fe}$ & $40.90(6.43)$ & $53.13(7.62)$ & $51.81(9.87)$ & $35.99(6.43)$ & $18.06(6.11)$ & $5.61(8.43)$ & $0.96(1.39)$ \\
\hline $\mathrm{Co}$ & $0.08(0.02)$ & $0.10(0.04)$ & $0.07(0.02)$ & $0.05(0.03)$ & $0.03(0.02)$ & $0.01(0.01)$ & $0.01(0.01)$ \\
\hline $\mathrm{Ni}$ & $0.01(0.01)$ & $0.01(0.02)$ & $0.02(0.02)$ & $0.01(0.01)$ & $0.01(0.01)$ & $0.01(0.01)$ & $0.01(0.01)$ \\
\hline As & $13.21(4.01)$ & $0.60(0.79)$ & $0.48(0.66)$ & $1.63(1.36)$ & $0.52(0.35)$ & $0.33(0.27)$ & $0.32(0.25)$ \\
\hline $\mathrm{Sb}$ & $1.32(1.18)$ & $1.30(1.28)$ & $2.19(2.42)$ & $19.19(6.62)$ & $40.11(6.94)$ & $45.30(8.86)$ & $41.07(4.66)$ \\
\hline $\mathrm{Cu}$ & $0.03(0.02)$ & $0.04(0.10)$ & $0.07(0.11)$ & $0.16(0.17)$ & $0.08(0.19)$ & $0.07(0.20)$ & $0.03(0.09)$ \\
\hline $\mathrm{Zn}$ & $0.04(0.03)$ & $0.03(0.05)$ & $0.04(0.06)$ & $0.05(0.04)$ & $0.02(0.02)$ & $0.03(0.09)$ & $0.02(0.03)$ \\
\hline $\mathrm{Pb}$ & $0.15(0.31)$ & $0.09(0.12)$ & $0.13(0.25)$ & $0.55(0.80)$ & $1.92(2.11)$ & $0.38(0.83)$ & $0.24(0.88)$ \\
\hline
\end{tabular}

The values listed are averages with standard deviations in parentheses; $n$ is the number of individual analyses averaged 

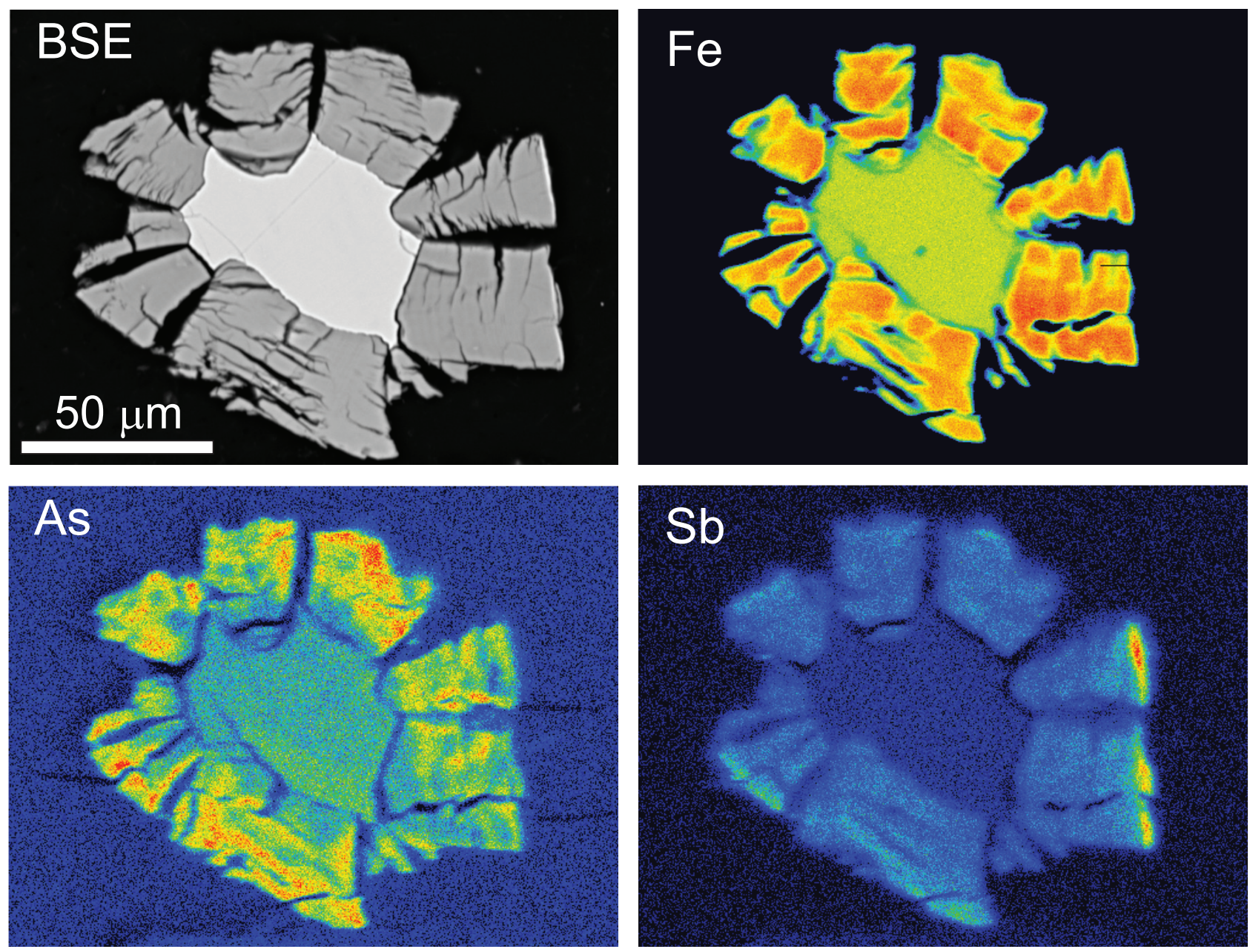

Fig. 6 A back-scattered electron (BSE) image of pyrite and its oxidation rim from the oxidation zone of the old impoundment at Dúbrava together with element distribution maps for Fe, As, and Sb. Note the enrichment of As and Sb towards the outer parts of the rims.

\subsubsection{Secondary Sb minerals}

Due to fast oxidation and dissolution of stibnite (Maruška et al. 2000), its presence in the oxidation zones of the tailings is minimal. At least some of the stibnite grains were transformed to secondary $\mathrm{Sb}$ oxides which occur frequently. Other grains may have been partially or completely dissolved in pore solutions. The dissolved antimony could be then adsorbed onto hydrous ferric oxides or precipitate to form $\mathrm{Sb}, \mathrm{Fe}-\mathrm{Sb}$, or $\mathrm{Sb}-\mathrm{Fe}$ oxides within the impoundment. A certain fraction of the dissolved $\mathrm{Sb}$ stays in solution and causes groundwater contamination (Ženišová et al. 2009).

At Dúbrava, the $\mathrm{Fe}-\mathrm{Sb}$ and $\mathrm{Sb}-\mathrm{Fe}$ oxides (Fig. 5, Tab. 1) are less common in the tailings than in the rims around pyrite and arsenopyrite crystals described above. $\mathrm{The} \mathrm{Fe}-\mathrm{Sb}$ and $\mathrm{Sb}-\mathrm{Fe}$ oxides are approximately equally abundant in all samples of sandy, oxidized tailings; the clayey tailings within the oxidation zones do not contain these phases at all. Textural evidence such as distinct
Tab. 2 Composition of an oxidation rim on a pyrite crystal from the oxidation zone of the old impoundment at Dúbrava (wt. \%)

\begin{tabular}{lrrr}
\hline \multicolumn{4}{c}{ location of the analysis } \\
& near the primary pyrite & middle & outer part of the rim \\
\hline $\mathrm{Mg}$ & 0.22 & 0.21 & 0.21 \\
$\mathrm{Al}$ & 0 & 0 & 0.03 \\
$\mathrm{Si}$ & 2.14 & 2.04 & 2.22 \\
$\mathrm{~S}$ & 0.23 & 0.11 & 0.09 \\
$\mathrm{P}$ & 0 & 0.01 & 0 \\
$\mathrm{Ca}$ & 2.39 & 2.4 & 2.51 \\
$\mathrm{Mn}$ & 0 & 0 & 0 \\
$\mathrm{Fe}$ & 52.09 & 51.13 & 52.47 \\
$\mathrm{Co}$ & 0.08 & 0.09 & 0.12 \\
$\mathrm{Ni}$ & 0 & 0 & 0.01 \\
$\mathrm{As}$ & 0.3 & 1.26 & 2.34 \\
$\mathrm{Sb}$ & 1.05 & 1.4 & 3.29 \\
$\mathrm{Cu}$ & 0 & 0.02 & 0.01 \\
$\mathrm{Zn}$ & 0.02 & 0 & 0 \\
$\mathrm{~Pb}$ & 0.02 & 0.02 & 0.07 \\
\hline
\end{tabular}



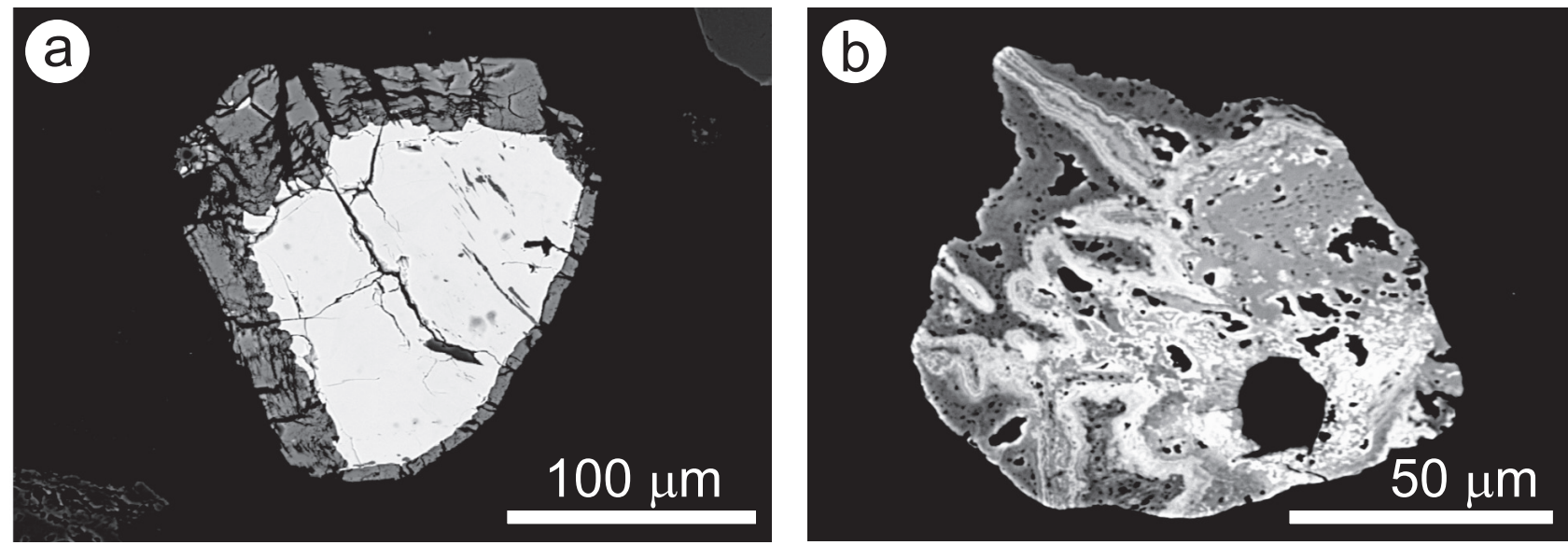

Fig. 7 Back-scattered electron images. a - Arsenopyrite and its oxidation rim from the oxidation zone of the old impoundment at Dúbrava; b - $\mathrm{A} \mathrm{Sb-Ca} \mathrm{oxide} \mathrm{from} \mathrm{a} \mathrm{depth} \mathrm{of} \mathrm{7-9.6} \mathrm{m}$ in the old impoundment in Dúbrava.

zoning suggests that the minerals crystallized from pore solutions in the tailing impoundments environment. Contents of As in the $\mathrm{Fe}-\mathrm{Sb}$ oxides are $0.35-4.29$ wt. \%, while the $\mathrm{Sb}$ concentrations vary from 10.89 to 29.01 wt. \% (Tab. 1).

$\mathrm{The} \mathrm{Sb}$ and $\mathrm{Sb}-\mathrm{Fe}$ oxides were identified in the material from the top oxidation zones (down to $2.5 \mathrm{~m}$ ) of the impoundments nos. 2 and 3 and from deeper parts $(7-12 \mathrm{~m})$ of the old impoundment. Similar minerals were present in lower amounts in the oxidation zone of the old impoundment (3-5 m). Similar to the case of the $\mathrm{Fe}-\mathrm{Sb}$ oxides, zoning of the grains causes their chemical heterogeneity.

Weathering products with much $\mathrm{Sb}$ and essentially no $\mathrm{Fe}$ were also observed and divided into two groups. The first group is characterized by high $\mathrm{Sb}$ as well as low $\mathrm{Fe}, \mathrm{As}$, and $\mathrm{Ca}$ contents. These $\mathrm{Sb}$ oxides are most likely a product of direct oxidation of stibnite, without any interactions with pore solutions; they are common especially in the oxidation zone of the old impoundment. The second group includes the more abundant $\mathrm{Sb}-\mathrm{Ca}$ oxides (Fig. 7b) with a significant content of $\mathrm{Ca}$ (up to 10.71 wt. \%, Tab. 1) and is most common in the younger impoundments.

\subsection{Poproč deposit}

\subsubsection{Geochemical characteristics of the tailings materials}

The largest impoundment (no. 3, Fig. 1) is formed by alternating layers of sandy and clayey sediments, each several $\mathrm{mm}$ to approximately $1 \mathrm{~m}$ thick. Sandy sediment is dominant in the top parts of the tailings, clayey material prevailing deeper. Sand-rich portions of the tailings are fully oxidised to a depth of $2 \mathrm{~m}$. The smaller impound- ments and piles of tailings scattered along the valley were not sampled in a detail comparable with impoundment no. 3. The content of the other impoundments and their oxidation zones, however, are probably very similar to those in the impoundment no. 3. Primary sulphides and especially products of their oxidation are concentrated in the sandy layers but were not found in the clayey sediment.

Chemically, the tailings are characterized by high $\mathrm{SiO}_{2}$ concentrations, elevated $\mathrm{MgO}$ contents, moderate to low $\mathrm{Al}_{2} \mathrm{O}_{3}, \mathrm{Fe}_{2} \mathrm{O}_{3}$, and $\mathrm{K}_{2} \mathrm{O}$ contents, and an especially striking lack of $\mathrm{CaO}$ (Fig. 3a). Concentration of both As and $\mathrm{Sb}$ are high, reaching maxima of 6800 and $15700 \mathrm{ppm}$, respectively (Fig. 3b). Except for a few outliers, the As/ $\mathrm{Sb}$ ratio varies near 1 (Fig. 4). The concentration of $\mathrm{Pb}$ is also high, of the order of thousands of ppm, reflecting the relatively abundant $\mathrm{Pb}-\mathrm{Sb}$ sulphosalts (Klimko et al. 2009). The contents of $\mathrm{Zn}$ and, to a lesser extent, $\mathrm{Cu}$ show significant scatter and can be explained by the rarity of sphalerite and tetrahedrite.

The $\mathrm{pH}$ values in the profiles POT -1 and POT -2 vary around averages of 4.00 and 4.35, respectively (Fig. 3a). The lowest measured $\mathrm{pH}$ value was 3.3 and the data show no discernible trend with sampling depth. The carbonate content of the tailings is essentially zero; an exceptional datum was 0.22 wt. \% calcite eq. The calculated neutralization potential of the tailing is $16-18 \mathrm{t}$ of $\mathrm{CaCO}_{3}$ per $1000 \mathrm{t}$. Static net acid generation tests indicated that the tailings in impoundment no. 1 could produce $0.78-2.65 \mathrm{~kg} \mathrm{H}_{2} \mathrm{SO}_{4} / \mathrm{t}$, and tailings in the impoundment no. 3 some $2.35-2.74 \mathrm{~kg} \mathrm{H}_{2} \mathrm{SO}_{4} / \mathrm{t}$.

\subsubsection{Oxidation products of pyrite and arsenopyrite}

Samples of tailing material collected at Poproč are characterised by an abundance of secondary oxides and 


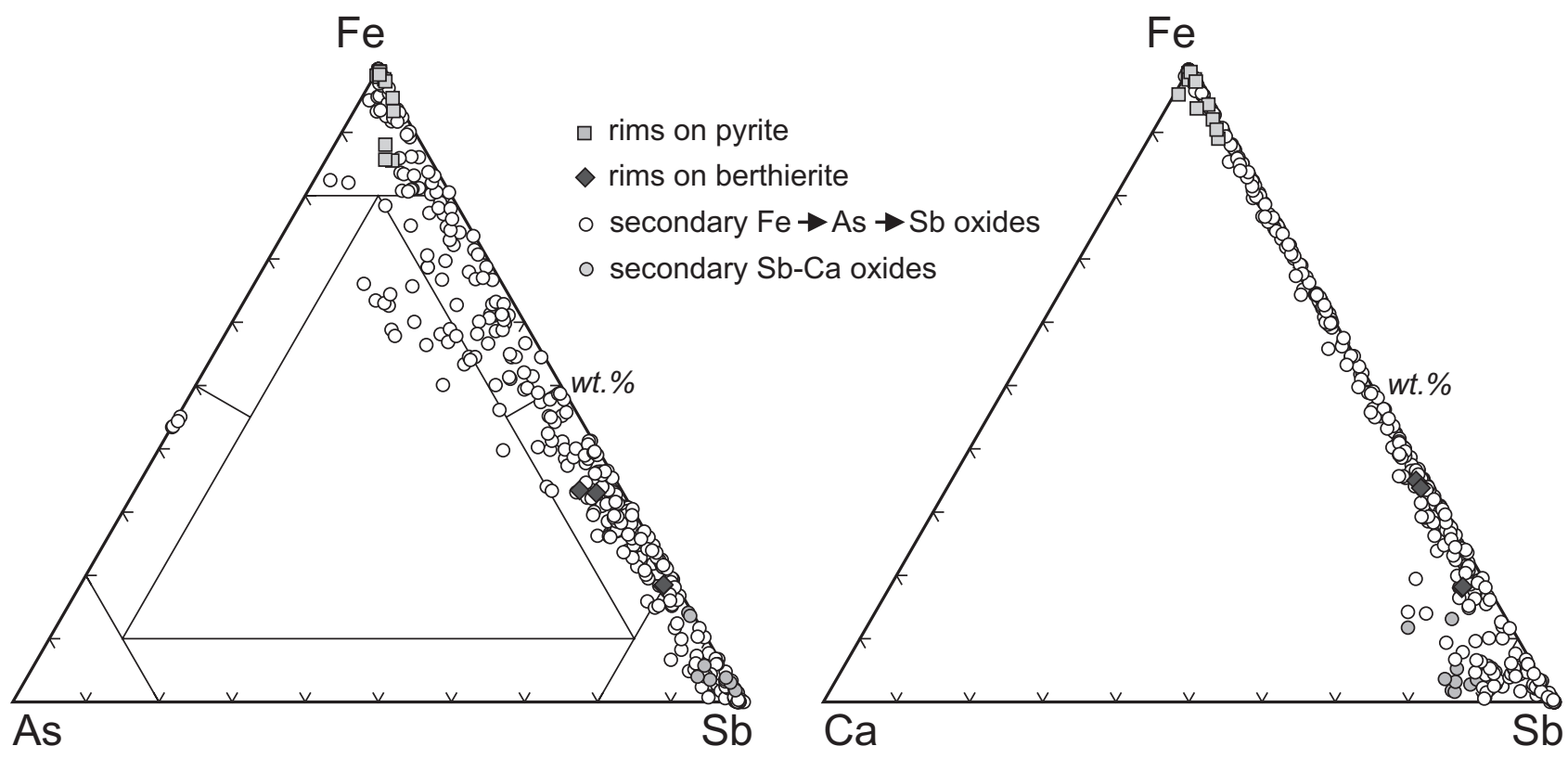

Fig. 8 Triangular plots of the chemical compositions of the rims on pyrite (squares), berthierite (diamonds), and grains with no relics of the primary sulphides (circles) from the tailings at Poproč. All data plotted are based on spot electron microprobe analyses. For the fields plotted in the left panel, see Fig. 2.

minimal contents of unweathered sulphides such as pyrite, arsenopyrite, stibnite and berthierite.

Pyrite was the most common sulphide and is, in most cases, replaced by pseudomorphs of secondary Fe oxides. Contents of Fe in these phases are 20.72-70.42 wt. \%; of Sb 0-9.56 wt. \% and As 0-9.87 wt. \% (Fig. 8, Tab. 3). Rarely, some of the primary pyrite remained and oxidation rims on such relics have contents of $\mathrm{Fe}$ from 38.65 to 60.19 , As from 0 to 3.21 and $\mathrm{Sb}$ from 0.16 to 4.20 wt. $\%$.

Arsenopyrite was a rare primary mineral in Poproč. Where it did occur, it was replaced in the tailings by scorodite $\left(\mathrm{FeAsO}_{4} \cdot 2 \mathrm{H}_{2} \mathrm{O}\right)$ which was identified by WDS analyses (Fig. 8, Tab. 3).

Tab 3 Composition of the weathering products from Poproč (wt. \%)

\begin{tabular}{|c|c|c|c|c|c|c|c|c|c|}
\hline element $/ n$ & $\begin{array}{c}\text { Sb-Fe oxides } \\
109\end{array}$ & $\begin{array}{c}\text { Sb oxides } \\
86\end{array}$ & $\begin{array}{c}\mathrm{Fe}-\mathrm{Sb} \text { oxides } \\
67\end{array}$ & $\begin{array}{c}\text { Fe oxides } \\
57\end{array}$ & $\begin{array}{c}\mathrm{Sb}-\mathrm{Ca} \text { oxides } \\
6\end{array}$ & $\begin{array}{c}\text { rims on } \\
\text { pyrite } \\
15\end{array}$ & $\begin{array}{c}\text { rims on } \\
\text { berthierite } \\
4\end{array}$ & $\begin{array}{c}\text { rims on } \\
\text { stibnite } \\
4\end{array}$ & $\begin{array}{c}\text { scorodite } \\
4\end{array}$ \\
\hline $\mathrm{Mg}$ & $0.10(0.09)$ & $0.07(0.05)$ & $0.12(0.16)$ & $0.12(0.17)$ & $0.09(0.04)$ & $0.06(0.04)$ & $0.13(0.06)$ & $0.08(0.03)$ & $0.04(0.03)$ \\
\hline $\mathrm{Al}$ & $0.75(0.99)$ & $0.54(0.93)$ & $0.80(0.90)$ & $0.80(1.31)$ & $0.28(0.13)$ & $0.71(1.03)$ & $0.09(0.07)$ & $0.27(0.17)$ & $0.07(0.08)$ \\
\hline $\mathrm{Si}$ & $1.05(1.57)$ & $1.06(0.91)$ & $2.20(2.35)$ & $2.06(2.38)$ & $1.71(0.73)$ & $2.02(1.08)$ & $0.27(0.05)$ & $0.91(0.22)$ & $0.08(0.11)$ \\
\hline $\mathrm{S}$ & $0.08(0.18)$ & $0.06(0.15)$ & $0.40(0.56)$ & $0.51(1.32)$ & $0.03(0.02)$ & $1.03(0.87)$ & $0.07(0.03)$ & $5.03(4.46)$ & $0.03(0.02)$ \\
\hline $\mathrm{P}$ & $0.10(0.10)$ & $0.06(0.09)$ & $0.21(0.16)$ & $0.20(0.29)$ & $0.04(0.03)$ & $0.09(0.11)$ & $0.05(0.05)$ & $0.00(0.01)$ & $0.01(0.02)$ \\
\hline $\mathrm{Ca}$ & $0.58(0.47)$ & $1.76(1.75)$ & $0.27(0.19)$ & $0.14(0.14)$ & $6.53(1.65)$ & $0.26(0.19)$ & $1.36(0.69)$ & $2.19(2.09)$ & $0.10(0.03)$ \\
\hline $\mathrm{Mn}$ & $0.03(0.06)$ & $0.01(0.01)$ & $0.03(0.08)$ & $0.09(0.11)$ & $0.05(0.04)$ & $0.03(0.04)$ & $0.07(0.07)$ & $0.01(0.01)$ & $0.00(0.00)$ \\
\hline $\mathrm{Fe}$ & $18.06(4.65)$ & $2.79(2.83)$ & $34.70(7.11)$ & $50.64(10.59)$ & $2.44(2.11)$ & $54.43(6.26)$ & $14.33(5.10)$ & $0.77(0.38)$ & $25.46(0.53)$ \\
\hline Co & $0.05(0.06)$ & $0.02(0.03)$ & $0.05(0.05)$ & $0.09(0.05)$ & $0.02(0.01)$ & $0.26(0.13)$ & $0.03(0.02)$ & $0.01(0.01)$ & $0.06(0.02)$ \\
\hline $\mathrm{Ni}$ & $0.02(0.03)$ & $0.01(0.02)$ & $0.03(0.17)$ & $0.04(0.15)$ & $0.01(0.02)$ & $0.02(0.03)$ & $0.01(0.01)$ & $0.01(0.02)$ & $0.04(0.05)$ \\
\hline As & $1.52(1.51)$ & $0.89(0.71)$ & $3.18(2.36)$ & $1.68(2.33)$ & $1.09(0.82)$ & $0.67(1.10)$ & $1.82(1.10)$ & $1.19(0.16)$ & $32.15(1.71)$ \\
\hline $\mathrm{Sb}$ & $40.92(8.26)$ & $53.19(8.40)$ & $17.29(4.67)$ & $3.51(3.06)$ & $44.69(9.29)$ & $1.30(1.59)$ & $38.95(4.64)$ & $39.06(2.53)$ & $0.15(0.09)$ \\
\hline $\mathrm{Cu}$ & $0.04(0.04)$ & $0.04(0.04)$ & $0.01(0.01)$ & $0.04(0.05)$ & $0.01(0.02)$ & $0.47(0.98)$ & $0.04(0.02)$ & $0.04(0.04)$ & $0.00(0.00)$ \\
\hline $\mathrm{Zn}$ & $0.26(0.30)$ & $0.13(0.23)$ & $0.09(0.11)$ & $0.13(0.17)$ & $0.05(0.05)$ & $0.40(0.33)$ & $0.28(0.31)$ & $0.02(0.02)$ & $0.05(0.03)$ \\
\hline $\mathrm{Pb}$ & $1.30(1.30)$ & $4.23(7.22)$ & $0.48(0.49)$ & $0.39(1.25)$ & $3.47(2.75)$ & $0.15(0.17)$ & $0.48(0.29)$ & $9.14(6.27)$ & $0.04(0.04)$ \\
\hline
\end{tabular}

The values listed are averages with standard deviations in parentheses; $n$ is the number of individual analyses averaged 


\subsubsection{Secondary Sb minerals}

Relics of stibnite are very rarely preserved in the tailings and if so, they are largely replaced by oxidation rims of variable composition. Contents of $\mathrm{Sb}$ in these rims range from 36.82 to $41.80 \mathrm{wt}$ \%, contents of Fe are low (0.50-1.33 wt. \%) and As varies between 1.04 and 1.38 wt. \% (Tab. 3). Interesting is the high $\mathrm{Pb}$ content (up to 15.76 wt. \%) in these oxidation rims, where it is probably adsorbed onto the secondary oxides from pore solutions. The source of $\mathrm{Pb}$ was likely the primary $\mathrm{Pb}-\mathrm{Sb}$ sulphosalts zinkenite and füllöpite, which are known to occur in the ores (Klimko et al. 2009) but were not found in the tailings. Care was taken to identify the primary sulphides by EDS analyses because the optical properties of stibnite and $\mathrm{Pb}-\mathrm{Sb}$ sulphosalts are rather similar. Therefore, we are sure that the $\mathrm{Pb}$-rich rims grew on stibnite and not on $\mathrm{Pb}-\mathrm{Sb}$ sulphosalts.
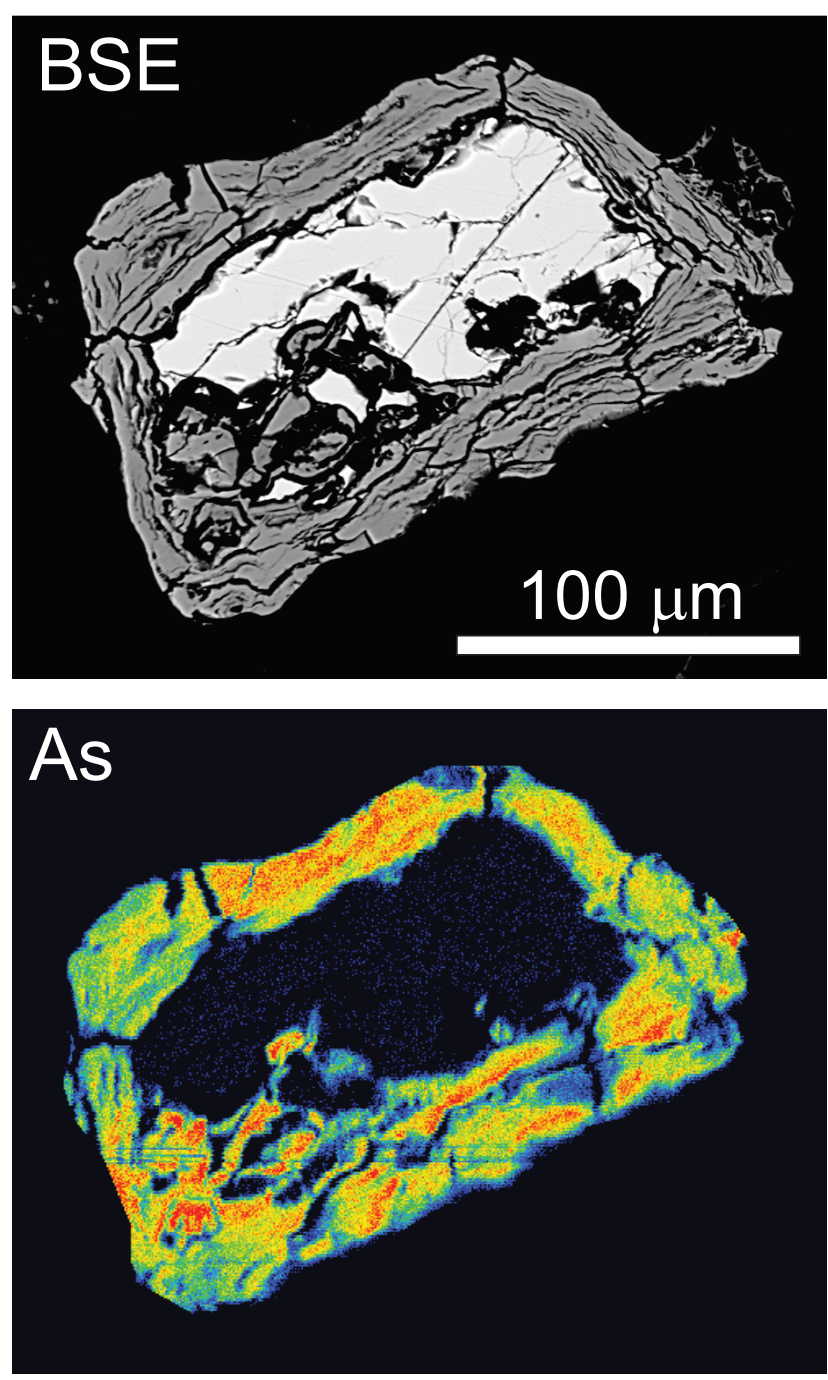

Berthierite was also identified in the samples and its crystals are occasionally replaced by oxidation rims (Fig. 9) with $\mathrm{Sb}$ contents of 34.64-43.59 wt. \%, As 0.90-3.27 wt. \%, and Fe 9.82-19.06 wt. \% (Tab. 3). An example of the distribution of $\mathrm{Sb}, \mathrm{As}$, and $\mathrm{Fe}$ in the rims on a berthierite crystal is displayed in Fig. 9. The oxidation rims are enriched in Fe and As and depleted in $\mathrm{Sb}$ compared with primary berthierite. Contents of $\mathrm{Sb}$ in oxidation rims are similar to those in primary berthierite, sometimes even a little lower, and most likely caused by $\mathrm{Sb}$ dissolution.

Secondary oxides with no relics of primary sulphides are the most abundant Sb- and As-bearing phases in the heavy fraction of the tailings from Poproč. As shown in Fig. 8, these phases span a wide range of compositions and include $\mathrm{Fe}, \mathrm{F}-\mathrm{Sb}, \mathrm{Fe}-\mathrm{As}-\mathrm{Sb}, \mathrm{Sb}-\mathrm{Fe}, \mathrm{Sb}$, and $\mathrm{Sb}-\mathrm{Ca}$ oxides. Phases in which $\mathrm{Sb}$ dominates over $\mathrm{Fe}$ are more abundant than those where $\mathrm{Fe}>\mathrm{Sb}$ (Fig. 8). Arsenic as-
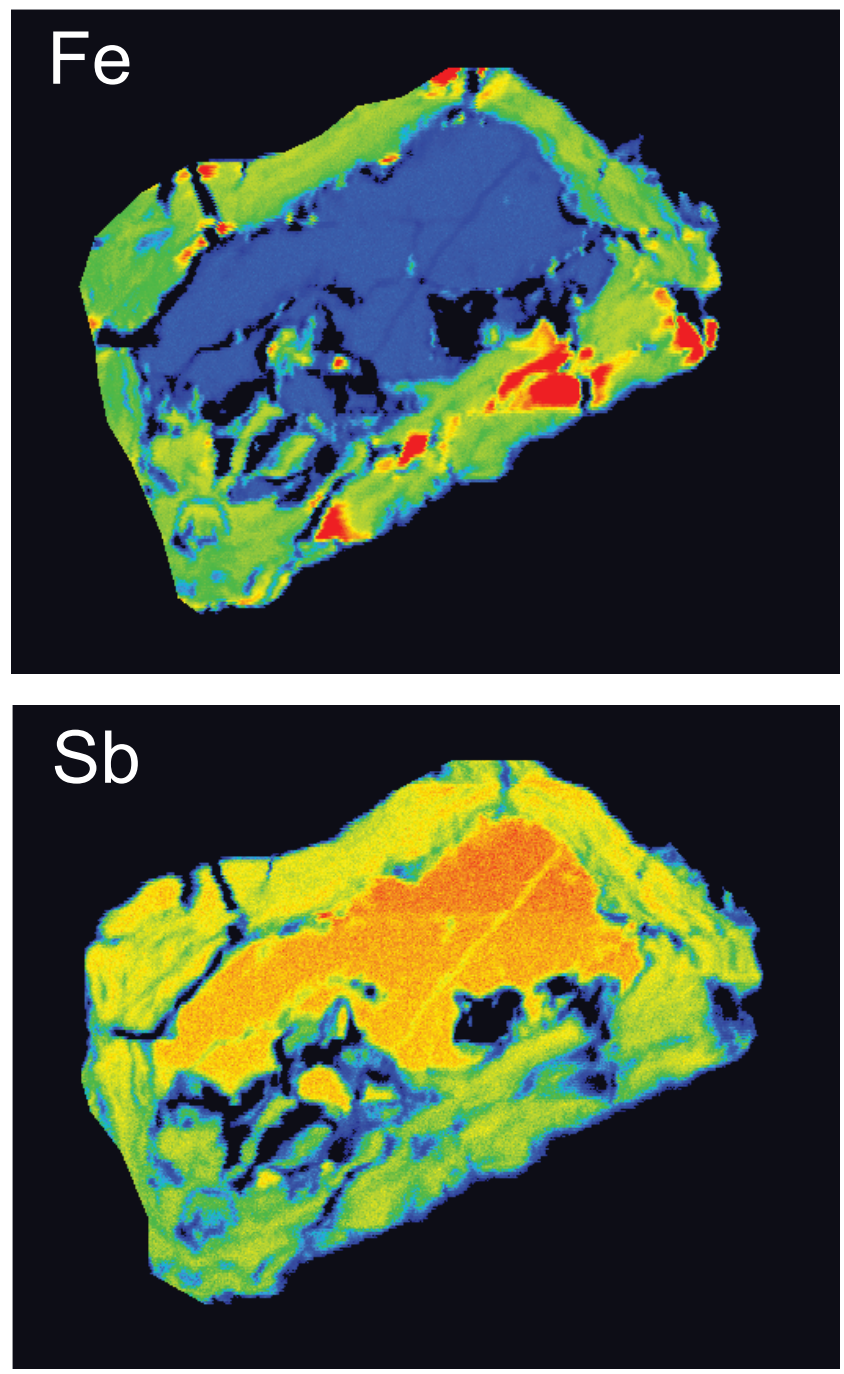

Fig. 9 A back-scattered electron image (BSE) of berthierite and its oxidation rim (impoundment no. 3 at Poproč) with element distribution maps for $\mathrm{Fe}, \mathrm{As}$, and $\mathrm{Sb}$. 

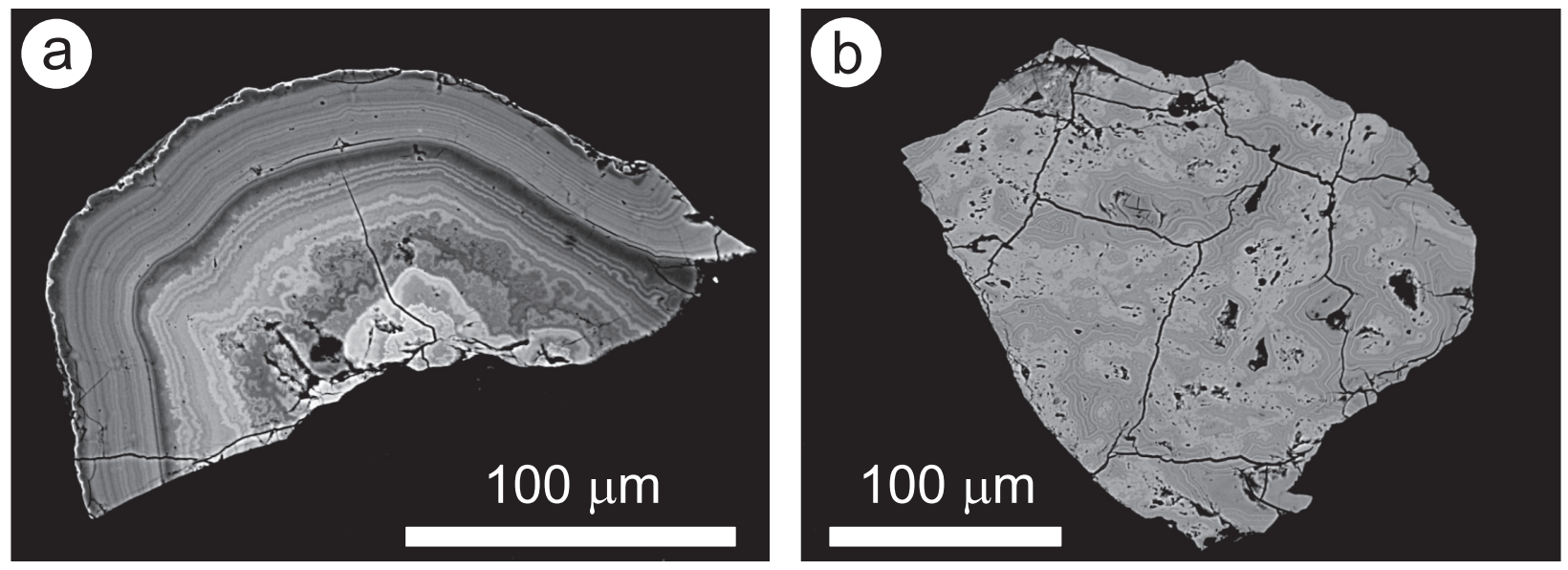

Fig. 10 Back-scattered electron images of two zoned grains from impoundment no. 3 at Poproč: Fe-Sb oxide (a) and Sb-Fe oxide (b).

sociates predominantly with the $\mathrm{Fe}-\mathrm{As}-\mathrm{Sb}$ and $\mathrm{Fe}-\mathrm{Sb}$ oxides (up to 9.87 wt. \%), less so with the $\mathrm{Sb}-\mathrm{Fe}$ oxides (Tab. 3). Both $\mathrm{Sb}-\mathrm{Fe}$ and $\mathrm{Fe}-\mathrm{Sb}$ oxides form often zoned grains (Figs 10a-b), either compact or porous. The Sbrich grains may contain elevated amounts of $\mathrm{Pb}$ (from 3.17 to 38.62 wt. \%) and there is a significant negative correlation $(-0.966)$ between $\mathrm{Pb}$ and $\mathrm{Sb}$ in grains with $\mathrm{Pb}$ contents over 5 wt. $\%$.

\section{Discussion}

Results of this study document qualitative and quantitative differences between secondary oxides at the studied sites and point to the different mineralogical and geochemical behavior of $\mathrm{As}$ and $\mathrm{Sb}$ in the environments of the impoundments. There are several parameters, which differentiate the two sites and may affect the rate and nature of the oxidation processes. The Dúbrava deposit is situated at a higher altitude (930-1 $300 \mathrm{~m}$ a.s.l.) than the Poproč deposit (356-630 m a.s.1.) and, therefore, the climate at Dúbrava is colder and oxidation processes are likely slower. Another difference is the mode of tailing deposition: at Dúbrava, the impoundments were properly built and later covered by layers of industrial waste from $20 \mathrm{~cm}$ to $250 \mathrm{~cm}$ thick. On the other hand, the tailings at Poproč were scattered along the valley and flotation waste lies in direct contact with air or surface waters. The oldest tailings in Dúbrava are 40-60, and those in Poproč 60-70 years old. All the mentioned conditions may have an influence on oxidation processes in the studied impoundments.

Iron contents in the tailings are higher at Dúbrava (average 11 wt. $\% \mathrm{Fe}_{2} \mathrm{O}_{3}$ ) than at Poproč ( 7 wt. $\% \mathrm{Fe}_{2} \mathrm{O}_{3}$ ), although chemical analysis alone says little about the nature of minerals that carry Fe (sulphides versus silicates). Antimony contents are much higher in tailings from
Poproč (average $5100 \mathrm{ppm}$ ) than from Dúbrava (1600 ppm) (Fig. 3). There are even greater differences in As contents, much higher at Poproč (average $3500 \mathrm{ppm}$ ) than at Dúbrava (500 ppm). Average $\mathrm{Pb}$ contents are $280 \mathrm{ppm}$ in tailings from Dúbrava and 1900 ppm from Poproč. The last element of importance that influences not only the chemical composition of the secondary minerals, but also the $\mathrm{pH}$ of the impoundments, is $\mathrm{Ca}$. Calcium is released from carbonates which are frequent in the tailings from Dúbrava but rare at Poproč. Consequently, Ca contents are high $(6 \mathrm{wt} . \% \mathrm{CaO})$ and $\mathrm{pH}$ is approximately neutral in the Dúbrava tailings; $\mathrm{Ca}$ contents are low (0.1 wt. \% $\mathrm{CaO})$ and the $\mathrm{pH}$ acidic at Poproč.

The most common sulphide at both sites is pyrite, less frequent being stibnite and arsenopyrite; minor berthierite was found only at Poproč. Our results confirm the previously published conclusions that pyrite is the slowest mineral to oxidize, followed by arsenopyrite (Buckley and Walker 1988; Richardson and Vaughan 1989; Nes-

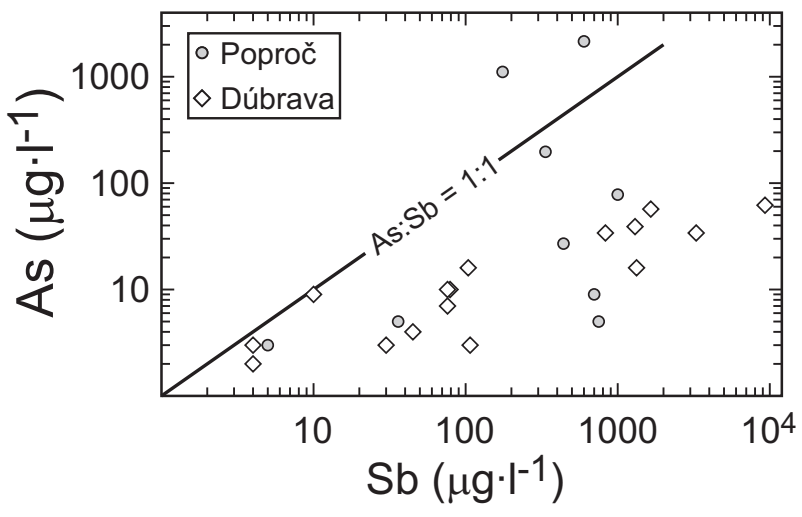

Fig. 11 Chemical composition of the aqueous solutions discharged from the old mines and impoundments at Dúbrava (diamonds) and Poproč (circles). All data are taken from Ženišová et al. (2009). Note the logarithmic scale on both axes. 
bitt et al. 1995; Nesbitt a Muir 1998; Filippi 2004). As already observed (Vink 1996; Maruška et al. 2000; Ashley et al. 2003; Wilson et al. 2004), stibnite oxidizes and decomposes quickly and is only rarely observed in oxidation zones.

The most frequent secondary phases in the Dúbrava impoundments are oxidation rims around pyrite and arsenopyrite, with relics of the primary sulphides frequently preserved. The rims are common in the oxidation zones of the impoundments and represent effective scavengers of both As and $\mathrm{Sb}$. Similar rims are largely missing in the acidic tailings at Poproč, mostly because the primary sulphides were completely oxidized and decomposed. The absence of sulphides at Poproč probably reflects the interplay of the acidic conditions within the impoundments (enhanced chemical weathering), the sandy nature of the tailings (enhanced water flow and better access of oxygen), and lower altitudes (higher average temperature).

A common feature of the oxidation rims around all primary minerals (pyrite, arsenopyrite, berthierite, stibnite) is an enrichment with respect to the elements not abundant in the primary phases; this effect is the most perceptible in the outermost portions of the rims. Rims on arsenopyrite may contain high amounts of $\mathrm{Sb}$, rims on pyrite abundant $\mathrm{As}$ and $\mathrm{Sb}$, and rims on stibnite elevated contents of $\mathrm{Pb}$. The most likely explanation for these observations is the adsorption of $\mathrm{As}, \mathrm{Sb}$, or $\mathrm{Pb}$ from the aqueous solutions, circulating through the impoundments. Indeed, the waters sampled at the two deposits (discharges from mines and impoundments) do contain excessive amounts of $\mathrm{Sb}$ and As (Fig. 11). It is interesting that these waters usually contain more $\mathrm{Sb}$ than $\mathrm{As}$ and are able to transport these two elements (in the fraction $<0.45$ $\mu \mathrm{m})$ even at circumneutral $\mathrm{pH}$ values.

Antimony is usually incorporated into $\mathrm{Sb}-\mathrm{Fe}, \mathrm{Fe}-\mathrm{Sb}$, $\mathrm{Sb}$, or Sb-Ca oxides (Majzlan et al. 2007; Chovan et al. 2010; Lalinská et al. 2010). As we have observed, the $\mathrm{Sb} /(\mathrm{Sb}+\mathrm{Fe})$ ratio may vary from 0 to 1 (Figs 5,8 ). Pure $\mathrm{Sb}$ oxides are more common in the tailings from Poproč and are probably pseudomorphs after stibnite. These phases may correspond to the minerals stibiconite $\left[\mathrm{Sb}^{3+} \mathrm{Sb}_{2}{ }^{5+} \mathrm{O}_{6}(\mathrm{OH})\right]$, cervantite $\left(\mathrm{Sb}^{3+} \mathrm{Sb}^{5+} \mathrm{O}_{4}\right)$, senarmontite $\left(\mathrm{Sb}_{2} \mathrm{O}_{3}\right)$, or valentinite $\left(\mathrm{Sb}_{2} \mathrm{O}_{3}\right)$, which are all known to be associated with weathering of $\mathrm{Sb}$ deposits (Chovan et al. 1981; Filella et al. 2002; Dill et al. 2008). The Sb-Fe oxide is the most likely tripuhyite $\left(\mathrm{FeSbO}_{4}\right)$, having presumably crystallized directly from pore solutions within the impoundments. The same phase was identified by micro-X-ray diffraction in the Sb-rich tailing impoundments from Pezinok (Slovakia) as a mineral controlling Sb distribution (Majzlan et al. 2011).

Behaviour of As is different from $\mathrm{Sb}$ in that the highest $\mathrm{As} /(\mathrm{As}+\mathrm{Fe}$ ) (in wt. \%) ratio observed was 0.41. The highest As concentration was detected in the $\mathrm{Fe}-\mathrm{As}$ oxides that form rims on arsenopyrite, the only primary sulphide with a substantial As content. Only the grains from Poproč plot in the field of the $\mathrm{Fe}-\mathrm{As}-\mathrm{Sb}$ oxides and these grains have in general higher As concentrations than those from Dúbrava. Enhanced adsorption of the arsenate anion to Fe-rich substrates can be easily understood as being the result of the acidic conditions at Poproč (Filella et al. 2002; Roddick-Lanzilotta et al. 2002; Smedley and Kinniburgh 2002). Scorodite, the most common stable product of arsenopyrite oxidation (Dove and Rimstidt 1985; Nordstrom and Parks 1987; Kraus and Ettel 1988; Alpers at al. 1994), was identified just in one sample from the Poproč deposit as the only As secondary mineral phase observed at both localities.

Calcium was found in low concentrations in nearly all identified phases, probably owing to electrostatic association with the small particles of the oxides (Voegelin et al. 2010). The highest concentrations of $\mathrm{Ca}$ were recorded in $\mathrm{Sb}-\mathrm{Ca}$ oxides from the most recent tailings at Dúbrava. These phases are chemically close to romeite, $\mathrm{Ca}_{2} \mathrm{Sb}_{2} \mathrm{O}_{7}$, described previously from oxidation zones of $\mathrm{Sb}$ deposits (Dill et al. 2008). It should be also noted that tailings with relatively low $\mathrm{Ca}$ contents, such as those at Poproč, contain $\mathrm{Sb}-\mathrm{Ca}$ oxides with elevated concentrations of $\mathrm{Ca}$.

Lead is bound most frequently to $\mathrm{Sb}-\mathrm{Fe}$, and less so to $\mathrm{Fe}-\mathrm{Sb}$ oxides at both localities, suggesting that the $\mathrm{pH}$ of the tailings does not play a decisive role for this element. Some of these oxides could correspond to bindheimite $\left(\mathrm{Pb}_{2} \mathrm{Sb}_{2} \mathrm{O}_{7}\right)$, which could be a product of $\mathrm{Pb}-\mathrm{Sb}$ sulphosalt oxidation (Bahfenne and Frost 2009).

\section{Conclusions}

The weathering products found at the two localities are chemically similar despite a number of physical and chemical differences between the two sites. The nature of these products is essentially controlled by primary mineralogy and the ability of the aqueous solutions to transport elements such as $\mathrm{As}, \mathrm{Sb}, \mathrm{Fe}, \mathrm{Ca}$, and $\mathrm{Pb}$. Under the observed conditions of high redox potential and moderately acidic to circumneutral $\mathrm{pH}$, aqueous solutions transport all these elements and enrich the weathering products in elements not available in the parental primary sulphides. A difference in the mineralogy of the weathering products could be perhaps expected under conditions which would mobilize some of these elements and separate them from the others, for example, at $\mathrm{pH}<2.5$ when $\mathrm{Fe}^{+3}$ is significantly soluble, or under reducing conditions, when more mobile $\mathrm{As}^{+3}$ dominates over $\mathrm{As}^{+5}$.

Pyrite is the slowest mineral to oxidize, followed by arsenopyrite. Stibnite oxidizes and decomposes quickly and is only rarely observed in oxidation zones. 
The differences in the mineralogy of the weathering products can be linked to the complete disappearance of the primary pyrite and arsenopyrite at Poproč; on the other hand, in Dúbrava their relics occur commonly. At both localities, stibnite weathers and decomposes rapidly. The $\mathrm{Fe}-\mathrm{Sb}$ and $\mathrm{Sb}-\mathrm{Fe}$ oxides are more abundant at Poproč, most likely as a consequence of the more abundant Fe supply into the pore solutions in the tailings from decomposing pyrite and arsenopyrite. Therefore, the differences appear to be the result of different rates of weathering and there is no indication that the final products would remain chemically or mineralogically distinct if weathering proceeded to the terminal stages. The only obvious difference is the enrichment of the weathering products in As at Poproč compared with Dúbrava. This fact can be explained easily by the higher As contents of Poproč tailings with the acidic conditions, under which the $\mathrm{AsO}_{4}^{3-}$ anion sorbs more strongly to Fe-rich weathering products.

These results are therefore applicable to other tailing ponds or mining dumps with high $\mathrm{Sb}$ concentrations. The data presented here could be used to predict which phases will appear in course of weathering of such tailings or dumps. We are currently studying more sites with high $\mathrm{Sb}$, using a combination of chemical and crystallographic analysis to determine precisely the nature of the minerals present. These results will be presented later in a separate contribution.

Acknowledgements. We thank M. Ude (University Jena, Germany) for XRF assistance and I. Holický (State Geological Institute of Dionýz Štúr, Bratislava) for help with electron microprobe analyses. This study was financially supported by the Slovak Research and Development Agency, grant no. APVV-0268-06, APVV-VMSP-0115-09 and the Deutsche Forschungsgemeinschaft, grant no. MA 3927/6-1. We thank to Pete Williams for the constructive criticism and V. Janoušek for the editorial handling of the manuscript.

Electronic supplementary material. The GPS coordinates and a map of the two localities as well as original electron microprobe analyses are available online at the Journal web site (http://dx.doi.org/10.3190/jgeosci.104).

\section{References}

Ackermann S, Gieré R, Newville M, Majzlan J (2009) Antimony sinks in the weathering crust of bullets from Swiss shooting ranges. Sci Total Environ 407: 1669-1682

Alpers CN, Blowes DW, Nordstrom DK, Jambor, JL (1994) Secondary minerals and acid mine-water chemis- try. In: JAMBOR JL, BLowes DW (eds) The Environmental Geochemistry of Sulfide Mine Waters. Mineral Association of Canada Short Course 22: 247-270

Arvensis M, Tupý P, Kupcová Z, Fodorová V, Mudráková M, Čechovská K, Čamaj P, KlaČan J (1994) Dúbrava - Impoundments, Preliminary Research. Unpublished manuscript, Slovak Geological Survey, Spišská Nová Ves, pp 1-188 (in Slovak)

Ashley PM, Craw D, Graham BP, Chappell DA (2003) Environmental mobility of antimony around mesothermal stibnite deposits, New South Wales, Australia and southern New Zealand. J Geochem Explor 77: 1-14

Bahfenne S, Frost RL (2009) Vibrational spectroscopic study of the antimonate mineral bindheimite $\mathrm{Pb}_{2} \mathrm{Sb}_{2} \mathrm{O}_{6}(\mathrm{O}, \mathrm{OH})$. Spectrochim Acta A74: 100-103

Blowes DW, Ptacek CJ, JuRJovec J (2003) Mill tailings: hydrogeology and geochemistry. In: JAMBOR JL, BLOWES DW, RitchiE AIM (eds) Environmental Aspects of Mine Wastes. Mineral Association of Canada, Short Course 31: $95-116$

BuCKLey AN, Walker W (1988) The surface composition of arsenopyrite exposed to oxidizing environments. Appl Surface Sci 35: 227-240

Chovan M, Horský S, Jeleñ S (1981) Cervantite from the stibnite deposits Dúbrava and Zlatá Baňa. Miner Slov 13: 233-234 (in Slovak)

Chovan M (1990) Mineralogical-paragenetical relations on the Dúbrava $\mathrm{Sb}$ deposit and their significance for metallogenesis of the Nízke Tatry Mts. Acta Geol Geog Univer Comen 45: 89-101

Chovan M, Háber M, Jeleñ S, Rojkovič I, Andráš P, Antal B (1994) Ore textures in the Western Carpathians. Slovak Academic Press, Bratislava, pp 1-219

Chovan M, Lalinská B, Šottník P, Hovorič R, Petrák M, KLimko T (2010) Mineralogical and geochemical characteristics of the contamination sources at the abandoned $\mathrm{Sb}-\mathrm{Au}$ ore deposit Medzibrod. Miner Slov 42: 95-108 (in Slovak)

ConkLIN AR (2005) Introduction to Soil Chemistry (Analysis and Instrumentation). John Wiley, Hoboken, New Jersey, pp 1-240

Corkhill CL, Vaughan DJ (2009) Arsenopyrite oxidation - a review. Appl Geochem 24: 2342-2361

Davis GB, Ritchie AIM (1986) A model of oxidation in pyritic mine wastes. 1. Equations and approximate solutions. Appl Math Model 10: 314-322

Dill HG, Melcher F, Botz R (2008) Meso- to epithermal W-bearing Sb vein-type deposits in calcareous rocks in western Thailand; with special reference to their metallogenetic position in SE Asia. Ore Geol Rev 34: 242-262

Dove PM, RimstidT JD (1985) The solubility and stability of scorodite, $\mathrm{FeAsO}_{4} \cdot 2 \mathrm{H}_{2} \mathrm{O}$. Amer Miner 70: 825-844

Filella M, Belzile N, Chen YW (2002) Antimony in the environment: a review focused on natural waters I. Occurrence. Earth Sci Rev 57: 125-176 
FiLIPPI M (2004) Oxidation of the arsenic-rich concentrate at the Prrebuz abandoned mine (Erzgebirge Mts., CZ): mineralogical evolution. Sci Total Environ 322: 271-282

Flynn HCA, Mechart AA, Bowyer PK, Paton GI (2003) Antimony bioavailability in mine soils. Environ Pollut 124: $93-100$

Grecula P, Abonyi A, Abonyiová M, Antaš J, Bartalský B, Bartalský J, DianišKa I, Drzík E, Ďuďa R, Gargulák M, GAZDočKo L', HudéčEK J, Kobulský J, Lörinz L, Macko J, NÁvesÑÁk D, Németh Z, Novotný L, RadvaneC M, RoJKovič I, RozložNík L, RozložNík O, VARČEK C, Zlocha J (1995) Mineral Deposits of the Slovenské Rudohorie Mts., vol. 1. Geokomplex, Bratislava, pp 1-834

JAMBOR JL (1994) Mineralogy of sulfide-rich tailings and their oxidation products. In: JAMBOR JL, BlowES DW (eds) The Environmental Geochemistry of Sulfide Mine Waters. Mineral Association of Canada, Short Course 22: $59-102$

JAMBOR JL (2003) Mine-waste mineralogy. In: JAMBOR JL, Blowes DW, Ritchie AIM (eds) Environmental Aspects of Mine Wastes. Mineral Association of Canada, Short Course 31: 117-145

Jambor JL, Dutrizac Je, Groat IA, Raudsepp M (2002) Static test of neutralization potential of silicate and alumosilicate minerals. Environ Geol 43: 1-17

Kuimko T, Chovan M, Huraiová M (2009) Hydrothermal mineralization of the stibnite veins in the Spišsko-gemerské rudohorie Mts. Miner Slov 41: 115-132 (in Slovak)

Kaličiaková E, Pacindová N, Rapčiak M, Seliga J, Volko P (1996): Final report Poproč - dumps, impoundments - VP environment status as of January 31, 1994. Unpublished manuscript, Archive of the State Geological Institute of Dionýz Štúr, Bratislava, pp 1-77 (in Slovak)

Kraus E, Ettel VA (1988) Solubility and stability of scorodite, $\mathrm{FeAsO}_{4} \cdot 2 \mathrm{H}_{2} \mathrm{O}$, new data and further discussion. Amer Miner 73: 850-854

Lalinská B, Chovan M, KuČerová G, Šottník P, Petrák M (2010) Processes of sulphide oxidation and As, Sb migration in the impoundment at the abandoned $\mathrm{Sb}-\mathrm{Au}$ ore deposit Čučma. Miner Slov 42: 79-94 (in Slovak)

Lowson RT (1982) Aqueous oxidation of pyrite by molecular oxygen. Chem Rev 82: 461-497

Majzlan J, Lalinská B, Chovan M, Jurkovič L', Milovská S, GötTLicher J (2007) The formation, structure, and ageing of As-rich hydrous ferric oxide at the abandoned $\mathrm{Sb}$ deposit Pezinok (Slovakia). Geochim Cosmochim Acta 71: 4206-4220

Majzlan J, Lalinská B, Chovan M, Bläss U, Brecht B, Göttlicher J, Steininger R, Hug K, Ziegler S, Gescher J (2011) A mineralogical, geochemical, and microbiogical assessment of the antimony- and arsenic-rich neutral mine drainage tailings near Pezinok, Slovakia. Amer Miner 96: 1-13
MarušKa M, Chovan M, ŠEvc J (2000) Mineralogical and environmental evaluation of the settling ponds at deposit Dúbrava in Nízke Tatry Mts. Slovak Geol Mag 6: 61-69

Miller S, Robertson A, Donahue T (1997) Advances in Acid Drainage Prediction using the Net Acid Generation (NAG) Test. Procedings of the $4^{\text {th }}$ International Conference on Acid Rock Drainage, Vancouver, BC, pp 533-549

Nesbitt HW, Muir IJ (1998) Oxidation states and speciations of secondary products on pyrite and arsenopyrite reacted with mine waters and air. Mineral Petrol 62: 123-144

Nesbitt HW, Muir IJ, Pratt AR (1995) Oxidation of arsenopyrite by air and air-saturated, distilled water, and implications for mechanism of oxidation. Geochim Cosmochim Acta 59: 1773-1786

NichoLson RV (1994) Iron-sulfide oxidation mechanisms: laboratory studies. In: JAMBOR JL, BLowEs DW (eds) The Environmental Geochemistry of Sulfide Mine Wastes. Mineralogical Association of Canada, Shourt Course 22: $164-183$

Nordstrom DK, Parks GA (1987) Solubility and stability of scorodite, $\mathrm{FeAsO}_{4} \cdot 2 \mathrm{H}_{2} \mathrm{O}$. Amer Miner 72: 849-851

Orvošová M, MaJzLAN J, CHOVAn M (1998) Hydrothermal alteration of granitoid rocks and gneisses in the Dúbrava $\mathrm{Sb}-\mathrm{Au}$ deposit, Western Carpathians. Geol Carpath 49: 377-387

Plumlee GS (1999) The environmental geology of mineral deposits. In: Plumlee GS, Logsdon MJ (eds) The Environmental Geochemistry of Mineral Deposits. Part A: Processes, Techniques and Health Issues. Reviews in Economic Geology, vol 6B: Littleton, Colorado, Soc Econ Geologists, 71-116

Richardson S, Vaughan DJ (1989) Surface alteration of pentlandite and spectroscopic evidence for secondary violarite formation. Mineral Mag 53: 213-222

Ritchie AIM (1994) Sulfide oxidation mechanism: controls and rates of oxygen transport. In: JAMBOR JL, BLOwES DW (eds) The Environmental Geochemistry of Sulfide Mine Waters. Mineral Association of Canada, Short Course 22: 210-245

Roddick-Lanzilotta AJ, McQuillan AJ, Craw D (2002) Infrared spectroscopic characterisation of arsenate $(\mathrm{V})$ ion adsorption from mine waters, Macraes Mine, New Zealand. Appl Geochem 17: 445-454

Sahan KH, Chovan M (1991) Thermometry of arsenopyrite-pyrite mineralization in the Dúbrava antimony deposit (Western Carpathians). Geol Carpath 42: 265-269

Seal RR, Hammarstrom JM (2003) Geoenvironmental models of mineral deposits: examples from massive sulfide and gold deposits. In: JAmbor JL, Blowes DW, Ritchie AIM (eds) Environmental Aspects of Mine Wastes. Mineral Association of Canada, Short Course 31: 11-50

Scheinost AC, Rossberg A, Vantelon D, Xifra I, Kretzschmar R, Leuz A-K, Funke H, Johnson CA(2006) 
Quantitative antimony speciation in shooting-range soils by EXAFS spectroscopy. Geochim Cosmochim Acta 70: 3299-3312

Smedley PL, KinNibURGH DG (2002) A review of source, behaviour and distribution of arsenic in natural waters. Appl Geochem 17: 517-568

Sobek AA, Schuller WA, Freeman JR, Smith RM (1978) Field and Laboratory Methods Applicable to Overburden and Mine Soils. U.S. National Technical Information Service Report EPA-600/2-78-054, Springfield, Virginia, pp 280-495

VINK BW (1996) Stability relations of antimony and arsenic compounds in the light of revised and extended $\mathrm{Eh}-\mathrm{pH}$ diagrams. Chem Geol 130: 21-30
Voegelin A, Kaegi R, Frommer J, Vantelon D, Hug SJ (2010) Effect of phosphate, silicate, and $\mathrm{Ca}$ on $\mathrm{Fe}(\mathrm{III})$ precipitates formed in aerated $\mathrm{Fe}(\mathrm{II})$ - and $\mathrm{As}(\mathrm{III})$-containing water studied by X-ray absorption spectroscopy. Geochim Cosmochim Acta 74: 164-186

Wilson NJ, Craw D, Hunter K (2004) Antimony distribution and environmental mobility at an historic antimony smelter site, New Zealand. Environ Pollut 129: 257-266

Žıvković Z, Š Trbac N, Žıvković D, Grujičić D, Boyanov B (2002) Kinetics and mechanism of $\mathrm{Sb}_{2} \mathrm{~S}_{3}$ oxidation process. Thermochim Acta 383: 137-143

ŽEnišová Z, Flaková R, Jašová I, Cicmanová S (2009) Antimony and arsenic in waters influenced by mining activities in selected regions of Slovakia. Podzem voda 15: 100-117 (in Slovak) 